\title{
Pedagogical Controlling in The System of Professional Pedagogical Engineering
}

\author{
Svetlana Dmitrievna Yakusheva ${ }^{1,2,3^{*}}$ \\ ${ }^{1}$ Institute of Professional Pedagogical Engineering, Moscow, Russia \\ ${ }^{2}$ International Academy of Sciences of Pedagogical Education (IASP), Moscow, Russia \\ ${ }^{3}$ Russian Academy of Natural Sciences (RAE), Moscow, Russia
}

\begin{abstract}
The last decade is characterized by increased variability of Russian education, its diversification and mobility, with a permanent reform of the national system on all levels. The education system sets a trajectory for the development of human potential required by modern society while forming a completely new situation and implementing breakthrough ideas. A key agent of modern education is pedagogical controlling of the system of professional and pedagogical engineering. The relevance of implementing pedagogical controlling in the sphere of general secondary education is a fait accompli. Since the significance of the educational services market has significantly increased in the context of modern economic development, directly influencing education which is an important branch of science and practice as well the intellectual product created within it. Russia's entry into the global education environment entails the convergence of the national education system with European counterparts. The authors believe that the system of professional and pedagogical engineering not only implements economic instrumentarium but also ensures the incorporation and support of innovative models of the education process. The article deals with the features of pedagogical controlling within the framework of the developed model (structure) of educational organization (complex) management within Moscow education.
\end{abstract}

\section{Introduction}

The $21^{\text {st }}$ century is the time of significant modifications in the Russian education system, implementation of innovative processes that require a reinterpretation of the content of general secondary education. As one determines the directions for development, the improvement of the flexible and versatile Moscow education system is ensured.

In view of this, the implementation of pedagogical controlling as part of the management system in a modern educational organization (complex) is a relevant topic of the study in modern pedagogical science and practice.

Moscow education is changing rapidly ensuring the advanced development of modern educational organizations (complexes). This refers to schools, kindergartens and centers for cultural and technical creativity, artistic and sports clubs, etc. Therefore, continuous

\footnotetext{
${ }^{*}$ Corresponding author: jawa57@mail.ru
} 
education (mentoring and teaching) is taking place in the following directions: preschool, elementary, basic general, secondary general (complete) and additional.

The rationale for the study consists, first of all, in designing and implementing pedagogical controlling as part of the professional and pedagogical engineering system in the development of an educational organization (complex) which is an integral educational system with several patterns and principles, while significantly changing management, planning, organization structure and mechanisms of control over the execution of decisions made.

The scientific novelty of the study consists in designing and implementing pedagogical controlling as part of the professional and pedagogical engineering system as a model (structure) of an educational organization (complex) management. The condition for the improvement of this activity is the innovative system of managing education processes horizontally and vertically.

The purpose of the study is the search for more optimal forms of managing an educational organization (complex) that radically improve the system of planning, accounting, analysis and quality of education.

While applying innovative models of strategic education development, educational organizations (complexes) ensure the implementation and proliferation of advanced pedagogical practices and are defining points for the development of scientific and methodological support of pedagogical education.

In the Moscow education system, innovative processes are taking place that radically modify the entire system, prioritizing professional and pedagogical engineering.

The importance of engineering is based not only on the high dynamics of the modern business world but also on the need to examine this direction in Russian educational space.

The English word "engineering" that stems from the Latin "ingenium" — ingenuity, fiction, knowledge. Dictionaries and studies contain different interpretations of engineering (Table 1).

Table 1. Definitions of the notion "engineering"

\begin{tabular}{|c|c|c|}
\hline $\begin{array}{l}\text { Oxford } \\
\text { Dictionary }\end{array}$ & - & $\begin{array}{l}\text { the activity related to applying scientific knowledge for the purpose } \\
\text { of designing, building and operating machines and engines. There is } \\
\text { mechanical engineering, chemical engineering and other types of } \\
\text { engineering according to industry sectors. In a more general sense, } \\
\text { the notion "engineering" is applied even to such fields as genetics, } \\
\text { finance, social sphere: genetic, financial and social engineering [1]. }\end{array}$ \\
\hline $\begin{array}{l}\text { The United } \\
\text { Nations } \\
\text { Economic } \\
\text { Commission for } \\
\text { Europe }\end{array}$ & - & $\begin{array}{l}\text { particular activities connected to the creation and operation of } \\
\text { enterprises and infrastructural facilities; a complex of design and } \\
\text { practical works and services that are part of the engineering and } \\
\text { technical field and are required for the construction of a facility and } \\
\text { the support of its operations [2]. }\end{array}$ \\
\hline $\begin{array}{l}\text { American } \\
\text { Engineers' } \\
\text { Council for } \\
\text { Professional } \\
\text { Development }\end{array}$ & - & $\begin{array}{l}\text { a wide range of actions and services provided by a consulting } \\
\text { company: from the preparation of statements of work and project } \\
\text { proposals, engineering survey works, including the construction of } \\
\text { new and reconstruction of existing industrial facilities, equipment } \\
\text { and technological techniques, to consultations of economic, financial } \\
\text { and other nature [3, p. 290]. }\end{array}$ \\
\hline $\begin{array}{l}\text { Definition } \\
\text { Dictionary }\end{array}$ & & $\begin{array}{l}\text { practice and methodology of using scientific and empirical } \\
\text { knowledge for the benefit of mankind [4]. }\end{array}$ \\
\hline $\begin{array}{l}\text { Dictionary of } \\
\text { Information } \\
\text { terms }\end{array}$ & & $\begin{array}{l}\text { the art or science of deriving practical benefits from pure scientific } \\
\text { knowledge, such as physics or chemistry, when designing structures } \\
\text { and buildings [5]. }\end{array}$ \\
\hline $\begin{array}{l}\text { French } \\
\text { dictionary "Le } \\
\text { lettre" }\end{array}$ & - & the search for one's own genius, thinking, means to succeed [6]. \\
\hline
\end{tabular}




\begin{tabular}{|c|c|}
\hline $\begin{array}{l}\text { Dictionary } \\
\text { "Petit Robert" }\end{array}$ & $\begin{array}{l}\text { - a global study of industrial projects in all aspects (technical, } \\
\text { economic, social) [7] }\end{array}$ \\
\hline V.A. Dyachenko & an instrument of innovative development of Russia [8]. \\
\hline L.K. Osika & $\begin{array}{l}\text { a type of innovative technologies including a complex of works on } \\
\text { the development of a project based on the creation, implementation, } \\
\text { promotion and expansion of a certain innovation from the moment of } \\
\text { conception to its realization }[9, \text { p. 13-14]. }\end{array}$ \\
\hline I.A. Radchenko & $\begin{array}{l}- \text { the provision of services related to bringing research and } \\
\text { experimental developments to the production stage }[10, p .109] \text {. }\end{array}$ \\
\hline
\end{tabular}

We believe that the efficiency of the development of an educational organization (complex) is achieved through the implementation of the professional and pedagogical engineering system that realizes the mechanism of developing, designing and management of the education process model, the presence of a scientific and methodological base that considers Russian and foreign experience and the experience of pedagogical controlling.

Since, professional and pedagogical engineering, being the unified educational system of modern educational organizations (complexes), makes it possible to unite innovative technological processes of organizational unit functioning into a single educational environment, thus providing all participants of the education process with chances of successful interaction.

Professional and pedagogical engineering is a set of processes that carry out the intellectual types of a pedagogue's professional activity (a pedagogue's formation and proficiency, etc.) and research and educational management (management-marketing environment and pattern engineering), the ultimate goal of which is the creative application of scientific methods and principles in the implementation of innovative projects (creating a flash case of the resource field and the formation of interaction mechanisms within the project consortium).

Engineering implements the system design of models of the educational process that consists of intellectual types of a pedagogue's professional activity and scientific and educational management (Figure 1) [11, p. 69-70].

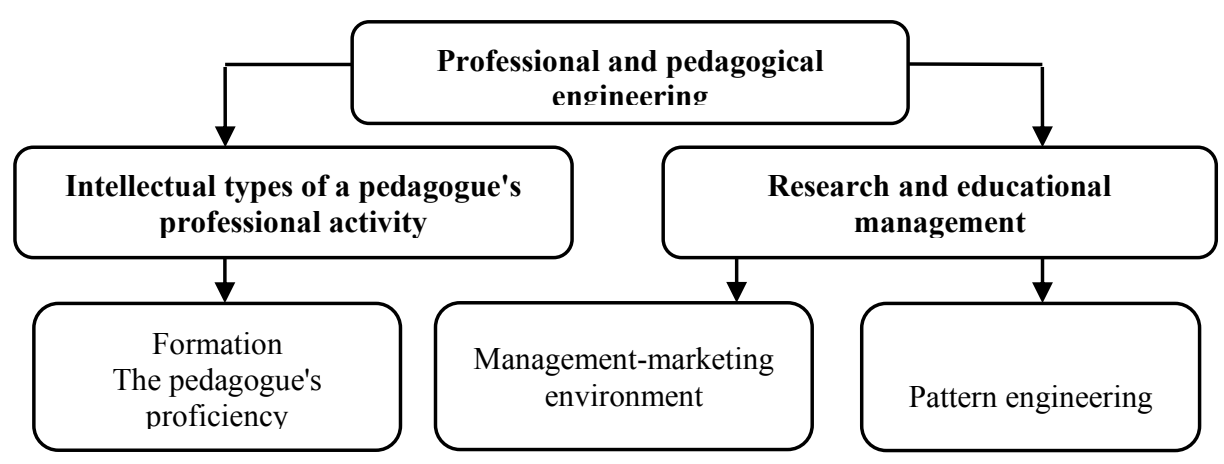

Figure 1. Professional and pedagogical engineering

We consider professional and pedagogical engineering according to the Federal Law of the Russian Federation №185-FZ dated 2 Jul. 2013, article 6, p.9 "the integration of science and education based on various forms of employees and students' participation in research and experimental development at higher education institutions through the creation of laboratories and departments in educational organizations". The transition to the management of an educational organization (complex) involves improving the entire system of planning, accounting, analysis and quality of education [12, p. 156]. 
P.I. Tretyakov argues that the most important object of management in an educational organization is the development process, as management science examines, first of all, the conditions for introducing novelties, innovations, modern pedagogical technologies and "the central object of management is the formation and development of all critical service systems of the main process at all types of educational institutions" [13, p. 7].

\section{Methods}

At the present stage of Russian education development, the need to transition to innovative education becomes logical. The introduction of professional and pedagogical engineering into the unified system of an educational organization (complex) makes it possible to unite innovative technological processes of organizational unit functioning into a single educational environment, thus providing all participants of the education process with chances of successful interaction.

In view of this, we have developed a model (structure) of educational organization (complex) management where pedagogical controlling is part of the management system. The educational organization (complex) functions as a system (Figure 2).

Model (structure) of educational organization (complex) management is an integrative system with vertical and horizontal management of educational organization components (research and methodological hub, departments, laboratories) with the purpose of consolidation in solving strategic, tactical and operative tasks, deepening the interaction and developing professional connections as a comprehensive process in the educational environment.

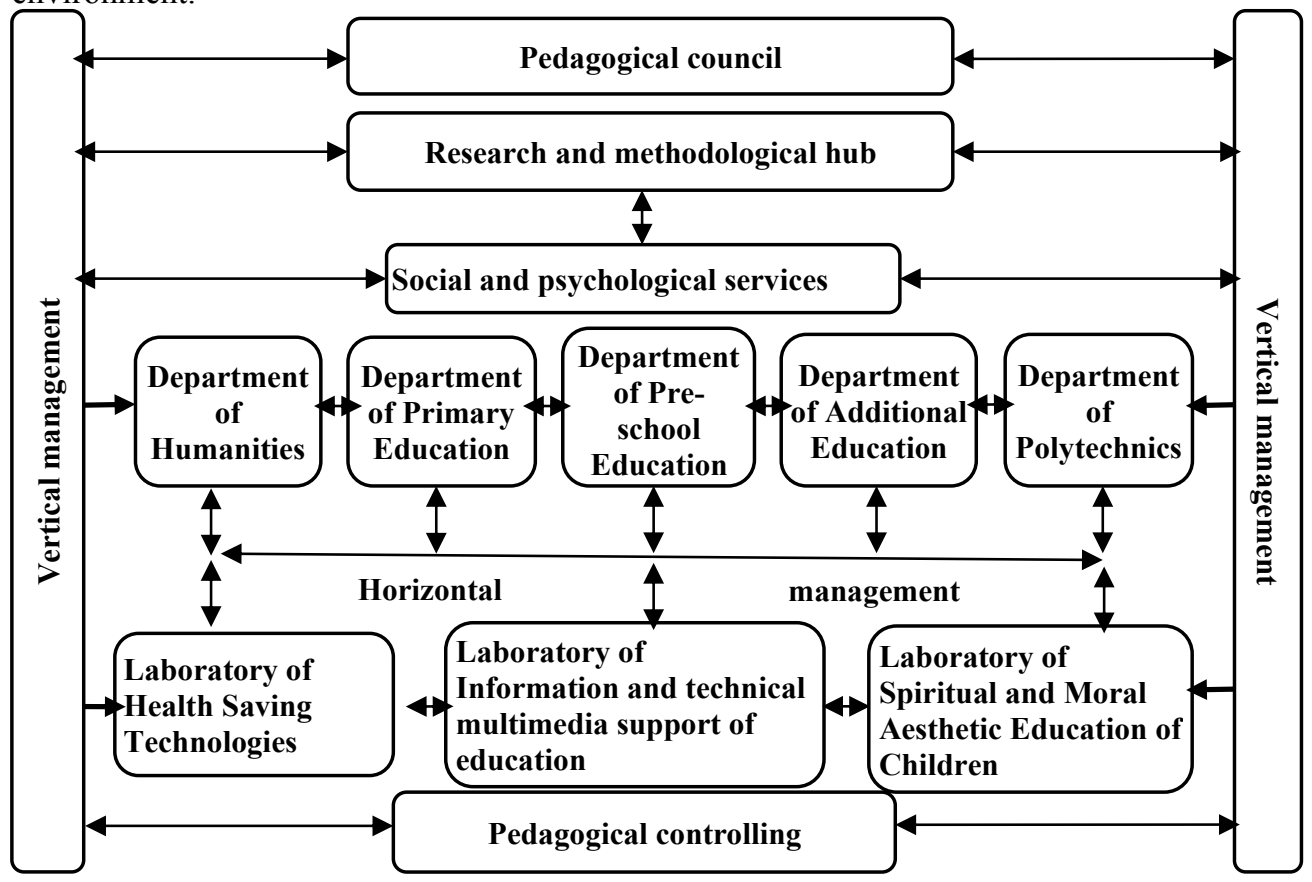

Figure 2. Model (structure) of educational organization (complex) management

Vertical management is an organizational level applied directly by the pedagogical council of an educational organization (complex) in relation to departments and laboratories in the process of achieving results in fulfilling strategic tasks of teaching and education defined by regulatory documents. 
Horizontal management is an organizational level applied directly by the heads of departments and laboratories, between the structural units of an educational organization (complex) and teachers, in the process of achieving results in fulfilling tactical tasks of teaching and education defined by regulatory documents.

Research and methodological hub is an organizational structure of the educational organization (complex) system that manages and supports scientific, methodological and research activities, as well as solves operational problems as they occur.

The main objective is the introduction of socially significant products and services in the field of secondary general education. It is possible to find an efficient solution for this field if there is a scientifically justified methodological framework that takes into account Russian and foreign experience, professional and pedagogical engineering that implements system design of educational process models and pedagogical controlling as part of the management system of the modern general education (complex) organization.

The term "controlling" (from the English to control) means to manage. In Russia, the interest in controlling arose in the early 1990s. The proliferation of controlling took place largely according to the European plan.

Organizations operating in various fields, such as manufacturing, the service industry, construction, transport, trade, education, etc. have taken more interest in controlling [14, p.3].

Thus, there are different approaches to understanding the essence of controlling in economic literature. Controlling is regarded as a management subsystem, a new management philosophy. Attempts are also made to define the place of controlling within management, the directions of its operation and methodological aspects of implementation into practical activities [15].

Sometimes "controlling" is associated with the word "control" but it is a different and even diametrical notion.

Control is directed to the past, aimed at determining the time of errors and miscalculations whereas controlling is the management of the present and the future that guarantees longterm operation of an educational organization and its structural units [16].

J. Weber and U. Schaeffer interpret controlling as an element of social system management aimed at supporting the leadership in the process of coordinating the management system, prioritizing the tasks of planning, control and information [17, p. 5].

Currently, there is no common definition for the notion "controlling" in Russian science. We have examined the most popular approaches to understanding the essence of controlling (Table 2).

Table 2. Definitions of the term "controlling"

\begin{tabular}{|c|c|}
\hline Authors & Various definitions of the term "controlling" \\
\hline M.I. Aliev & $\begin{array}{l}\text { a new tool in the theory and practice of management that contains elements } \\
\text { of budgeting, managerial accounting, economic analysis and management }[18, p .5] \text {. }\end{array}$ \\
\hline $\begin{array}{l}\text { I.F. } \\
\text { Elfimova }\end{array}$ & $\begin{array}{l}\text { integration of accounting, analysis, planning, regulation and control into a } \\
\text { single system of obtaining, processing, summarizing information and making } \\
\text { managerial decisions on its basis }[19, \text { p. } 136] \text {. }\end{array}$ \\
\hline $\begin{array}{l}\text { E. Mayer } \\
\text { R. Mann }\end{array}$ & $\begin{array}{l}\text { a system for managing the process of achieving the ultimate goals and results } \\
\text { of the organization activities }[20, \text { p. } 20] \text {. }\end{array}$ \\
\hline S.V. Rubtsov & $\begin{array}{l}\text { a system providing a methodological and instrumental framework (MIF) to } \\
\text { support the basic managerial functions: planning, control, accounting and analysis } \\
{[21, \text { p. 3]. }}\end{array}$ \\
\hline $\begin{array}{l}\text { S.A. } \\
\text { Smirnov }\end{array}$ & - $\quad$ a set of tasks related to monitoring, planning and management [22, p. 6]. \\
\hline $\begin{array}{l}\text { T.Yu. } \\
\text { Teplyakova }\end{array}$ & $\begin{array}{l}\text { management for the provision a methodological instrumentarium to support } \\
\text { the basic functions of management: planning, control, accounting and analysis, as } \\
\text { well as assessing the situation to make managerial decisions }[23, \mathrm{p} .11] \text {. }\end{array}$ \\
\hline
\end{tabular}




\begin{tabular}{|l|l|}
\hline S.G. Falco & $\begin{array}{l}- \text { a system of information and analytical, methodological and instrument } \\
\text { support of the managers of an enterprise (organization) to achieve their goals, } \\
\text { focused on long-term and efficient development, ensuring the realization of the } \\
\text { management cycle in all functional areas and processes by assessing resources and } \\
\text { performance results [14, p. 45]. }\end{array}$ \\
\hline $\begin{array}{l}\text { D. Hahn } \\
\text { H. } \\
\text { Hungenberg }\end{array}$ & $\begin{array}{l}- \text { a system of integrated information support, planning and control of the } \\
\text { enterprise (organization) activity [24]. }\end{array}$ \\
\hline P. Horvath & $\begin{array}{l}- \text { a management subsystem that coordinates the subsystems of planning, control } \\
\text { and information support, thus supporting system-forming and system-reconciling } \\
\text { coordination [25]. }\end{array}$ \\
\hline $\begin{array}{l}\text { N.N. } \\
\text { Shlyago }\end{array}$ & $\begin{array}{l}- \text { a form of the management process that occurs in such socio-economic systems } \\
\text { implementation of all stages of the management cycle [26, p.6]. }\end{array}$ \\
\hline
\end{tabular}

Therefore, based on the researchers' concepts, we state that controlling is extensively applied in the management system of enterprises (organizations).

The role and place of pedagogical controlling in an educational organization management system is not sufficiently researched by Russian scholars.

The above creates numerous practical problems for the functioning of pedagogical controlling in Russian educational organizations which requires a scientific approach to solving the problems.

\section{Conclusion}

The analysis of the theory and practice of controlling allows one to conclude that it is necessary to introduce pedagogical controlling into the system of a modern educational organization (complex).

For, pedagogical controlling of the professional and pedagogical engineering system complements the management of the complex at a completely new level, integrating, coordinating and directing the activities of structural units to achieve strategic, tactical and operational goals and objectives facing the educational organization (complex).

Pedagogical controlling is an efficient component of the management system of an educational organization (complex) that evaluates the quantitative and qualitative parameters of the activities of structural units to create a relevant management model in solving strategic problems.

The study of pedagogical controlling is the process and result of scientific and practical activities which is aimed at obtaining new knowledge in the technology of managing structural units of an educational organization (complex).

From 2006 to 2017, an experiment was conducted in the use of pedagogical controlling at ten Moscow educational organizations (complexes). The results determined the validity of the experiment. In the process of studying pedagogical controlling, the relevance in the management system of an educational organization (complex) was proved.

We believe that the presented Model (Figure 1) allows us not only to evaluate the efficiency of vertical and horizontal management in an educational organization (complex) but also to consider pedagogical controlling in the management system as a whole.

Therefore, pedagogical controlling improves the efficiency of the educational organization (complex) management system through information-analytical and methodological support, decision-making processes, ensuring coordination and implementation of planning, control and analysis.

We think that pedagogical controlling, as an innovative direction of the system of professional and pedagogical engineering, helps to improve the quality of education and 
creates real opportunities for its optimization, expanding the range of innovative activities in the system of an educational organization (complex), meets modern requirements and can be used to improve management efficiency.

\section{References}

1. Concise Oxford English Dictionary: For University and College Studentes (Oxford University Press, Oxford, 2006)

2. United Nations Economic Commission for Europe. Official site. Available at: http://www.unece.org

3. S.D. Yakusheva, Science, Technology and Higher Education, Materials of the IV International research and practice conference, 30 January 2014, Westwood, Canada (2014)

4. Dictionary of Definitions. Available at: www.mijnwoordenboek.nl/definition

5. Dictionary of information terms. Available at: www.dictionary.infoplease.com

6. French dictionary "Le letter". Available at: http://lingvo.mail.ru/?lang_id=1036\&text=lettre

7. Dictionary "Petit Robert". Available at: http://rutracker.org/forum/viewtopic.php?t=2813048

8. V.A. Dyachenko, Engineering as a tool to accelerate the innovative development of Russia. Available at: http://www.osp.ru/resources/releases/?rid=4193

9. L. Osika, EnergoRynok, 4 (2010) Available at: http://www.uppro.ru/library/modernization/engineering/sovremennij-inzhiniring.html

10. I.A. Radchenko, Educational Dictionary of Advertising Terms and Public Relations (VF MGEI, Voronezh, 2007).

11. S.D. Yakusheva, Scientific and educational management of professional pedagogical engineering of the organization of general education. Pedagogical management in education: current issues of modern science: Monograph (Publishing House SibAK, Novosibirsk, 2015)

12. S.D. Yakusheva, Scientific journal, 9-10, 149-158 (2014)

13. P.I. Tretyakov, S.I. Zakharenkov, M.V. Tuberozova, N.A. Sharay, Pedagogical marketing in the management of the development of educational systems (Publishing House of the CA "Perspective", Moscow, 2010)

14. S.G. Falco, Controlling for managers and professionals (Finance and Statistics, Moscow, 2008)

15. S.V. Osipov (Ed.), Controlling: theory and practice: a textbook and a workshop for academic undergraduate (Publishing house Yurayt, Moscow, 2017).

16. A.M. Karminsky and S.G. Falco (Eds.), Controlling at an industrial enterprise (Publishing house FORUM; INFRA-M, Moscow, 2014)

17. J. Weber, U. Schäffer, Introduction to Controlling (Publishing House of NP "Association of Controllers", Moscow, 2014)

18. M.I. Aliev, Controlling at agribusiness enterprises: A short course of lectures (Saratov State Agrarian University, Saratov, 2017)

19. A.N. Asaul, I.V. Drozdova, M.G. Kvitsiniya, A.A. Petrov, Cost Management and Controlling: Textbook. manual for universities (Publishing house Yurayt, Moscow, 2017) 
20. R. Mann, Controlling for beginners (Finance and Statistics, Moscow, 2004)

21. S.V. Rubtsov, Controlling as the quintessence of scientific management. Economics of modern Russia, Materials of the All-Russian Conference 28-30 November, Moscow, Russia (2000)

22. S.A. Smirnov, Controlling: Textbook (Moscow International Institute of Econometrics, Informatics, Finance and Law, Moscow, 2002)

23. T.Yu. Teplyakova. Controlling: Textbook (UlSTU, Ulyanovsk, 2010)

24. D. Khan, Planning and control - the concept of controlling (Finance and Statistics, Moscow, 2015)

25. E.L. Popchenko, N.B. Ermasova, Business controlling (Alfa-Press, Moscow, 2008)

26. N.N. Shlyago, Controlling: textbook and workshop for academic (Publishing house Yurayt, Moscow, 2018) 